J. Amer. Soc. Hort. Sci. 118(1):73-76. 1993.

\title{
Pesticide Effect on Acetylene Reduction and Modulation by Soybean and Lima Bean
}

\author{
Lih-Yuh Yueh ${ }^{1}$ and David L. Hensley ${ }^{2}$ \\ Department of Horticulture, Forestry and Recreational Resources, Kansas State University, Manhattan, \\ KS 66506
}

\begin{abstract}
Additional index words. Glycine max, Phaseolus lunatus, mode of action
Abstract. The influence of 12 pesticides on acetylene reduction $\left(\mathrm{N}_{2}\right.$ fixation) and modulation of soybean (Glycine max L. Merrill cv. Williams 82) and lima bean (Phaseolus lunatus L. cv. Geneva) was evaluated. All pesticides except diazinon were found to be harmless to nitrogen fixation at $3 \times$ the manufacturer's recommended rate, Diazinon significantly decreased $\mathrm{C}_{2} \mathrm{H}_{2}$ reduction of soybean 2 days after application, but not after 7 days or at normal label rates, Acetylene reduction of excised nodules imbibed with diazinon indicated that the chemical may have affected nitrogenase function directly. Soybean nodule counts were significantly decreased by application of $3 \times$ rates of methomyl and trifluralin, whereas lima bean nodule counts were decreased only by trifluralin. Tritluralin also depressed soybean modulation at label rates, but had no effect on lima bean modulation. Methomyl was innocuous to soybean modulation at the recommended label rate. Both chemicals were nontoxic to Bradyrhizobium/Rhizobium sp. based on a disc inhibition study. Chemical names used: $O, O$-diethyl $O$-(2isopropyl-4-methyl-6-pyrimidinyl phosphorothiote (diazinon); S-Methul- $N$-((methylcarbamoyl)oxy)-thioacetimidate (methomyl); a,a,a -Trifluoro-2-6dinitro- $N$ - $N$-dipropyl-p-toluidine (triflnralin).
\end{abstract}

Pesticides are important tools of modern agricultural production that can protect crop yield and quality. A variety of pesticides are registered for use on legume crops. The information available on their influence on modulation or nitrogenase function of plants is incomplete and sometimes inconsistent.

Lima bean and soybean are two widely grown grain legumes. Scant published information exists concerning the impact of pesticides on $\mathrm{N}_{2}$ fixation and modulation by lima bean, and none is available for many other legumes. Soybean is the primary legume crop in the world; thus, a significant volume of research has been developed. In many instances, however, the results are contradictory.

Kust and Struckmeyer (1971) and Parker and Dowler (1976) found that the herbicide trifluralin suppressed soybean modulation, whereas Bollich et al. (1985) reported that it did not affect soybean $\mathrm{C}_{2} \mathrm{H}_{2}$ reduction, nodule number, or dry weight. A study by AlaaEldin et al. (1981) showed that trifluralin at five times the label rate stimulated soybean modulation, but Mallik and Tesfai (1985) reported adverse results on modulation. Modulation of dry bean $(P$. vulgaris L.) was not affected by trifluralin and 3-isopropyl-1- $H$ 2,1,3-benzothiadiazin-4( $3 H$ ) -one 2,2-dioxide (bentazon) (Fischer and Tasistro, 1981), but $\mathrm{N}_{2}$ fixation of dry bean was rapidly decreased by bentazon (Bethlenfalvay et al., 1979; Schnelle and Hensley, 1990),

Likewise, inconsistency exists in reports on the effect of fungi-

Received for publication 9 Apr. 1992. Accepted for publication 24 Aug. 1992. Contribution no. 90474J of the Kansas State Univ. Agricultural Experiment Station, Manhattan. This material is based on work supported by the Cooperative State Research Service, USDA, under Agreement 88340503531 and the Agriculture Special Grants Program under Agreement 86CRSR2 2775. Any opinion, findings, and conclusions or recommendations expressed in this publication are ours and do not necessarily y reflect the views of the USDA, Bradyrhizobium japonicum strain 61 A118 and Rhizobium leguminosarum biovar phaseoli strain 127E15, were kindly provided by Peter Wong, Division of Biology, Kansas State Univ., Manhattan. We thank Edward Hellman and Steven Wiest for editing this manuscript. The cost of publishing this paper was defrayed in part by the payment of page charges. Under postal regulations, this paper therefore must be hereby marked advertisement solely to indicate this fact.

${ }^{1}$ Former Graduate Research Assistant,

${ }^{2}$ Associate Professor. Present address: Dept. of Horticulture; Univ. of Hawaii; 3190 Maile Way; Honolulu, HI 96822. tides on various legumes. Curley and Burton (1975) found that Pentachloronitrobenzene (PCNB) reduced soybean taproot nodulation, whereas Mallik and Tesfai (1985) reported that it was innocuous, even at 10 times the label rate.

The insecticides 1-Naphthy1 $N$-methylcarbamate (carbaryl) and $O, O$-dimethyl phosphordithoate of diethyl mercaptosuccinate (malathion) had no adverse effect on soybean at the recommended levels, but severely reduced $\mathrm{N}_{2}$ fixation at 10 times the label rates (Mallik and Tesfai, 1985). O,S -dimethyl acetylphosphoramidothioate(acephate), diazinon, and Chlorinated camphene (toxaphene) also reduced $\mathrm{N}_{2}$ fixation and total $\mathrm{N}$ content, but not growth or modulation of soybean at either rate. Carbaryl, diazinon, 4,4Dichloro-alpha-trichloro-methylbenzhydrol (dicofol), and malathion did not cause any injury to dry bean (Schnelle and Hensley, 1990).

The cause of reduced modulation and $\mathrm{N}_{2}$ fixation by pesticides has not been studied extensively. Some decline has been associated with impaired foliage or root growth by the host plants (Fischer and Tasistro, 1981) or reduction of energy supply to the nodules (Bethlenfalvay et al., 1979; Ljunggren and Martensson, 1980). Other researchers have studied the effect of chemicals directly on Rhizobium. Kapustra and Rouwenhorst (1973) screened commercial formulations of 24 pesticides for bacteriostatic activity against $R$. japonicum using a gradient-plate technique. Isopropyl m-chlorocarbanilate (Chlorpropham) and $O, O$-Diethyl S-[2(ethylthio)ethyl] phosphoro-di-thioate (disulfoton) were the only pesticides that inhibited growth. They found marked differences in resistance of $R$. japonicum strains to various pesticides, which was also reported by Staphorst and Strijdom (1976), Tu (1980), and Mallik and Tesfai (1983),

The objectives of this research were to determine the effects of 12 pesticides on $\mathrm{N}_{2}$ fixation (acetylene reduction) and modulation of soybean and lima bean and to study the mode of action of pesticides that affected $\mathrm{N}_{2}$ fixation and modulation of these plants.

\section{Materials and Methods}

Seeds of 'Williams 82' soybean and 'Geneva' lima bean were inoculated with Bradyrhizobium japonicum (strains 61A101 and 61A118) and Rhizobium leguminosarum biovar phaseoli (strain 
127E15), respectively, before planting in plastic cell packs (7.6× $7.6 \times 7.6 \mathrm{~cm})$. Seedlings were thinned to one plant per cell and grown in a greenhouse $(16 \mathrm{~h}, 30 \mathrm{C}$ day; $8 \mathrm{~h}, 25 \mathrm{C}$ night $)$ in a 5 sand $: 1$ loam (v/v). Plants were fertilized periodically with nitrogenfree nutrient solution (Hoagland and Arnon, 1950).

Postemergence pesticides were applied when seedlings were at the three trifoliate-leaf stage in the $\mathrm{C}_{2} \mathrm{H}_{2}$ reduction fixation study or when they had one set of true leaves in the modulation study. Preemergence materials were applied on the day of planting for both studies. All pesticides were applied at triple $(3 \times)$ the manufacturer's label rate (Table 1). Foliar-applied postemergence materials were sprayed to runoff with a chlorofluorocarbon aerosol sprayer, whereas bentazon, PCNB, and trifluralin were applied over the tops of plants or soil in measured amounts of distilled, deionized water. All control plants were sprayed with distilled, deionized water only. All treatments and controls were replicated five times, and each study was repeated. Chemicals that showed an effect on $\mathrm{C}_{2} \mathrm{H}_{2}$ reduction or modulation were studied at the recommended label rate $(1 \times)$ in separate evaluations using the same methods.

$\mathrm{C}_{2} \mathrm{H}_{2}$ reduction. Nodules were harvested from treated and control plants 2 and 7 days after application of postemergence pesticides or 6 weeks after application of preemergence pesticides, An acetylene reduction assay was performed using modified techniques described by Hensley and Carpenter (1979) to determine N, fixation ability of excised nodules. Excised nodules were placed in stoppered culture tubes $(22 \mathrm{ml})$ and $2 \mathrm{ml}$ of air was replaced with acetylene. Nodules were incubated at $28 \mathrm{C}$ for $1 \mathrm{~h}$ and $0.5-\mathrm{ml}$ samples were withdrawn for analysis using disposable syringes (1 $\mathrm{ml})$. Accumulation of ethylene was determined in earlier studies to be linear during the assay period. A automated gas chromatography (Varian 6000), with a stainless steel Porapak R column, was used for all assays. Column, injector, and ionization temperatures were 50,90 , and $105 \mathrm{C}$, respectively. Nodules were dried for $24 \mathrm{~h}$ at $80 \mathrm{C}$ before being weighed.

Acetylene reduction rates were expressed in nmoles ethylene/ grams of nodule dry weight per hour. One-way analysis of variance (ANOVA) was performed on all data after log transformations (Ott, 1984).

Modulation. Counts per plant and weights of oven dried nodules were determined 4 weeks after treatment with postemergence chemicals or 6 weeks after treatment with preemergence chemicals. Data were analyzed statistically by means of one-way ANOVA.

Nitrogenase. Potential modes of action of pesticides that showed inhibitory effects on acetylene reduction or modulation were evaluated. Soybean nodules were exposed to diazinon to determine if the insecticide directly impeded nitrogenase function. Detached nodules from untreated soybean plants were placed in test tubes containing $9.6,19.2,38.4,76.8$, or $115.2 \mathrm{ml}$ of diazinon/liter $(0.25 \times, 0.5 \times, 1.0 \times$, $2.0 \times$, or $3.0 \times$ label rates) or distilled water and vacuum-infiltrated by faucet aspiration for $1 \mathrm{~h}$ to allow for the penetration of chemical. Nodules were then removed, blotted, and acetylene reduction assay performed.

Rhizobium. A modified microbial disc inhibition test similar to that described by Tu (1980) and Mallik and Tesfai (1983) was used to determine if trifluralin and methomyl influenced Bradyrhizobium/ Rhizobium populations directly. B, japonicum strain 61A118 and $R$. leguminosarum biovar phaseoli strain $127 \mathrm{E} 15$ were grown in yeast extract mannitol agar (YEMA) (Vincent, 1970). Cell suspensions of Bradyrhizobium/Rhizobium cultures were obtained by incubation in YEMA broth for 1 to 2 days at $28 \mathrm{C}$ on a shaker. Filter paper discs ( $8 \mathrm{~mm}$ in diameter) were soaked in $1 \times, 2 \times$, or $3 \times$ labelrate solutions of methomyl $\left(6.25,12.5\right.$, or $18.75 \mathrm{ml} \cdot$ liter $\left.^{-1}\right)$ or tri- fluralin $(1,2$, or $3 \mathrm{ppm})$ or in distilled water for $45 \mathrm{~min}$.

Plates were seeded with $0.1 \mathrm{ml}$ of the inoculum $(\approx 107$ cells $/ \mathrm{ml})$ to $5 \mathrm{ml}$ of unsolidified YEMA $(0.75 \%$ agar $)$ and spread uniformly. Four air-dried filter paper discs containing various concentrations of a pesticide were placed on the plate, equidistant from each other. Plates were incubated at $28 \mathrm{C}$ for 7 days, and the zones of growth inhibition surrounding the discs were measured and compared to controls.

\section{Results and Discussion}

$\mathrm{C}_{2} \mathrm{H}_{2}$ reduction. Diazinon was the only pesticide examined at $3 \times$ label rate that had a significant effect on $\mathrm{C}_{2} \mathrm{H}_{2}$ reduction by soybean (Table 1). This insecticide decreased $\mathrm{N}$, fixation of soybean within

Table 1. Influence of pesticides ( $3 \times$ label rate) on nitrogen fixation (acetylene reduction) by soybean and lima bean. Separate controls were used for each pesticide.

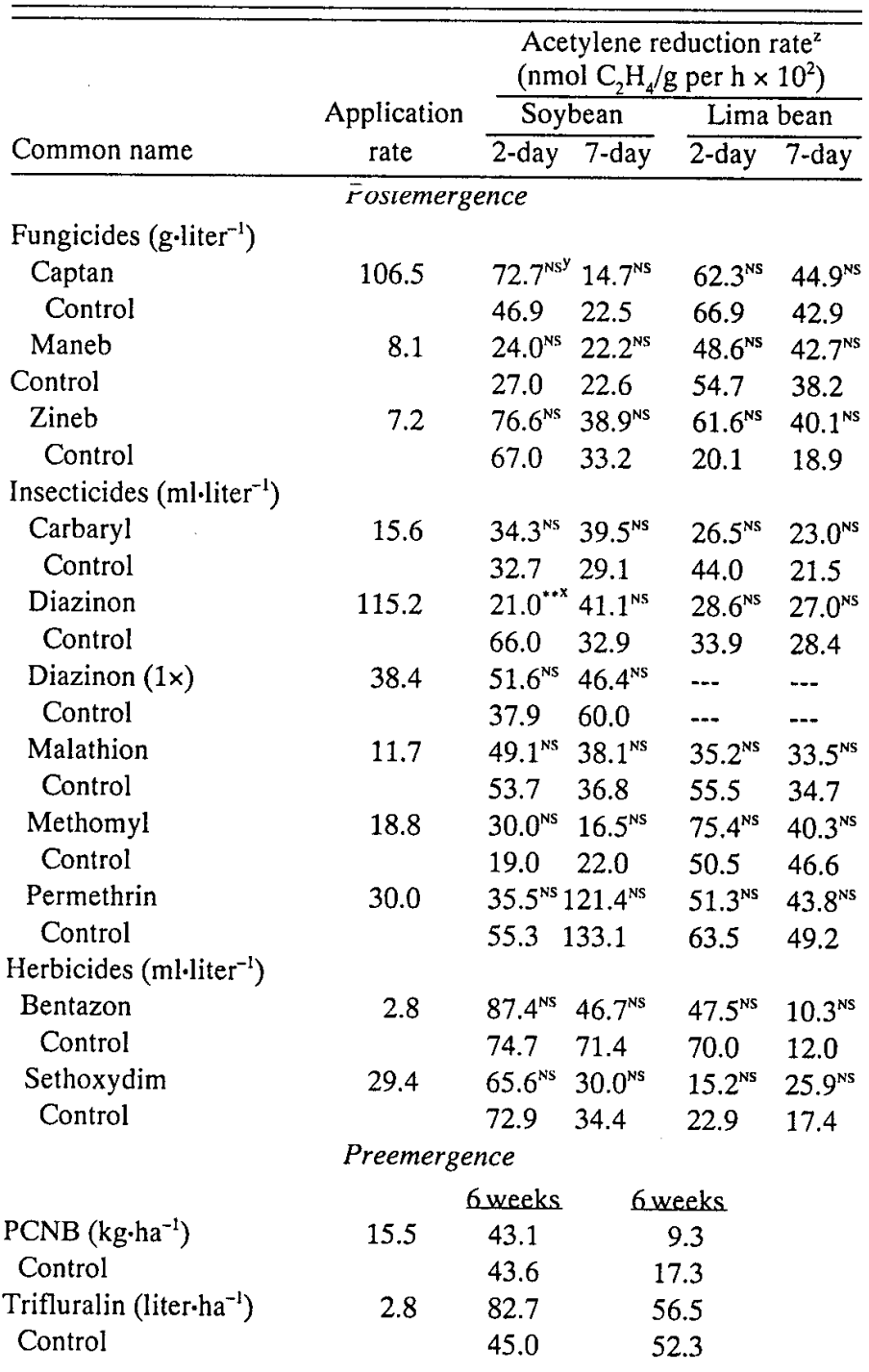

${ }^{2}$ Data represents an average of five replications per treatment of one experiment.

${ }^{y}$ Each control is to be compared with its paired pesticide, not among all of the pesticides or controls. Data were acquired over several months, asindicated by the variability in acetylene reduction capacity. Control values can be expected to vary since acetylene reduction rates will change with temperature, light, and other environmental conditions.

'Significant at $P=0.05$. 
2 days. However, this reduction was not evident 7 days after treatment. Diazinon had no effect when applied at the label rate (Table 1). No pesticide significantly affected $\mathrm{C}_{2} \mathrm{H}_{2}$ reduction by lima bean.

The results presented are those of separate, repeated studies conducted over a period of several months. Variation among the various controls and treatments over the course of the study is to be expected due to changes in solar radiation and other environmental variables. No comparison other than between the paired control and treatment is intended or should be made.

Soybean nodule counts were significantly reduced by $3 x$ applications of methomyl and trifluralin, whereas the number of lima bean nodules was decreased only by trifluralin (Table 2). The average dry weights of nodules of neither plant were affected, however. In separate studies using label rates, trifluralin still depressed soybean modulation, but had no effect on lima bean. Label rates of methomyl did not significantly affect soybean modulation.

Table 2. Influence of pesticides on average number of nodules and average nodule weight per plant of soybean and lima bean. Separate controls were used for each pesticide, with application rates listed in Table 1.

\begin{tabular}{|c|c|c|c|c|}
\hline \multirow[b]{3}{*}{ Common name } & \multirow{2}{*}{\multicolumn{2}{|c|}{$\frac{\text { Soybean }}{\text { Nodules/plant }}$}} & \multirow{2}{*}{\multicolumn{2}{|c|}{$\frac{\text { Lima bean }}{\text { Nodules/plant }}$}} \\
\hline & & & & \\
\hline & $\overline{\text { No. }}$ & Wt (mg) & No. & Wt (mg) \\
\hline \multicolumn{5}{|l|}{ Fungicides } \\
\hline Captan & $38.0^{2}$ & 1.70 & 146.0 & 0.68 \\
\hline Control & $36.4^{y_{N S} x}$ & $2.12^{\mathrm{NS}}$ & $108.4^{\mathrm{NS}}$ & $0.64^{\mathrm{NS}}$ \\
\hline Maneb & 60.0 & 1.21 & 132.2 & 0.51 \\
\hline Control & $61.8^{\mathrm{Ns}}$ & $0.99^{\mathrm{NS}}$ & $127.2^{\mathrm{NS}}$ & $0.54^{\mathrm{Ns}}$ \\
\hline Zineb & 44.0 & 1.64 & 144.0 & 0.44 \\
\hline Control & $40.0^{\mathrm{NS}}$ & $1.61^{\mathrm{Ns}}$ & $125.0^{\mathrm{NS}}$ & $0.65^{\mathrm{NS}}$ \\
\hline PCNB & 28.6 & 1.53 & 90.6 & 0.46 \\
\hline Control & $33.0^{\mathrm{NS}}$ & $1.32^{\mathrm{NS}}$ & $102.2^{\mathrm{NS}}$ & $0.37^{\mathrm{Ns}}$ \\
\hline \multicolumn{5}{|l|}{ Insecticides } \\
\hline Carbaryl & 31.2 & 2.06 & 122.8 & 0.50 \\
\hline Control & $25.4^{\mathrm{NS}}$ & $2.81^{\mathrm{Ns}}$ & $144.0^{\mathrm{NS}}$ & $0.44^{\mathrm{Ns}}$ \\
\hline Diazinon & 36.8 & 1.71 & 111.2 & 0.54 \\
\hline Control & $44.2^{\mathrm{NS}}$ & $2.12^{\mathrm{NS}}$ & $109.5^{\mathrm{NS}}$ & $0.57^{\mathrm{Ns}}$ \\
\hline Malathion & 36.2 & 1.94 & 185.2 & 0.39 \\
\hline Control & $42.0^{\mathrm{NS}}$ & $1.83^{\mathrm{NS}}$ & $123.0^{\mathrm{NS}}$ & $0.50^{\mathrm{NS}}$ \\
\hline Methomyl & 25.8 & 1.88 & 99.0 & 0.50 \\
\hline Control & $41.0^{* w}$ & $1.81^{\mathrm{NS}}$ & $110.0^{\mathrm{Ns}}$ & $0.46^{\mathrm{NS}}$ \\
\hline Methomyl (1x) & 41.8 & 1.95 & $\cdots$ & -.. \\
\hline Control & $37.2^{\mathrm{Ns}}$ & $1.74^{\mathrm{NS}}$ & -- & -- \\
\hline Permethrin & 34.2 & 1.84 & 136.6 & 0.47 \\
\hline Control & $37.8^{\mathrm{NS}}$ & $1.55^{\mathrm{NS}}$ & $114.0^{\mathrm{NS}}$ & $0.47^{\mathrm{NS}}$ \\
\hline \multicolumn{5}{|l|}{ Herbicides } \\
\hline Bentazon & 23.4 & 1.32 & 108.8 & 0.44 \\
\hline Control & $33.2^{\mathrm{NS}}$ & $1.18^{\mathrm{Ns}}$ & $94.4^{\mathrm{NS}}$ & $0.42^{\mathrm{NS}}$ \\
\hline Sethoxydim & 71.2 & 1.18 & 66.2 & 0.79 \\
\hline Control & $74.2^{\mathrm{NS}}$ & $1.23^{\mathrm{NS}}$ & $69.0^{\mathrm{NS}}$ & $0.62^{\mathrm{NS}}$ \\
\hline Trifluralin & 3.6 & 1.86 & 34.2 & 0.71 \\
\hline Control & $18.0^{* * v}$ & $1.45^{\mathrm{NS}}$ & $70.4^{* *}$ & $0.44^{\mathrm{Ns}}$ \\
\hline Trifluralin (1x) & 12.0 & 0.84 & 55.7 & 0.89 \\
\hline Control & $22.6^{* *}$ & $1.66^{* *}$ & $60.5^{\mathrm{Ns}}$ & $0.70^{\mathrm{Ns}}$ \\
\hline
\end{tabular}

${ }^{\mathrm{z} D a t a}$ represents an average of five replications per treatment of one experiment.

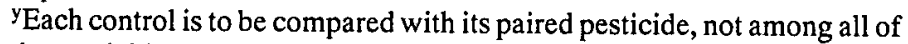
the pesticides or controls.

${ }^{\mathrm{N}}$ Not significantly different (F test, $P=0.05$ ).

"Significant at $P=0.05$ level (F test).

vignificant at $P=0.01$ level (F test). cis- $N$-Trichloromethylthio-4-cyclohexene-1,2-dicarboximide (Captan),Manganese ethylenebisdithiocarbamate (maneb),PCNB, Zinc ethylenebisdithiocarbamate (zineb), carbaryl, malathion, (3phenoxyphenyl)methyl(1)cis, trans-ethenyl-2,2-di-methylcyclopropane-carboxylate (permethrin), bentazon, and 2[1(ethoxyimino)butyl]-5-[2-(thylthio)propyl]-3-hydroxyl-2cyclohexen-1-one (sethoxydim) at elevated rates had no effect on nitrogen fixation by soybean or lima bean. These results conflict with the findings of some earlier studies (Chamber and Montes, 1982; Curley and Burton, 1975). Such variation in plant response may be expected because of differences in plant cultivars, Rhizobium strains, or in experimental technique (Mallik and Tesfai, 1983, 1985; Wax et al., 1974).

The various results for soybean and lima bean demonstrate that differences exist between species in response to the same pesticide. Lima bean appeared to be less sensitive to pesticides than soybean. Soybeans treated with the $3 \times$ rate of sethoxydim at the first trifoliate leaf stage displayed "bronzing" of exposed leaves 1 day after application, but no such injury was observed on lima bean. This may have been due to the waxy leaf surface of lima bean.

Trifluralin had a dramatic effect on plants when applied at the $3 \times$ rate. Soybean root growth was obviously limited; lateral roots that developed were short and thickened. Shoot growth was also restricted, probably as a result of limited root growth. Kust and Struckmeyer (1971) reported xylem occlusion in the roots and internodes of trifluralin-treated soybean. They suggested a direct relationship between root effects and top growth effects because reduction in water transport may decrease mineral nutrient transport.

Nodulation. Trifluralin was detrimental to modulation of both legumes, especially soybean (Table 2). Average nodule count per treated soybean was one-fifth that of control plants. Lima bean modulation was reduced by about one-half. Even the recommended rate of trifluralin somewhat adversely affected modulation. Similar results were reported by Mallik and Tesfai (1985). Because trifluralin is a major herbicide for weed control in soybean, its rate of application should be evaluated carefully.

Once nodules were successfully formed on the roots after trifluralin treatment, $\mathrm{N}_{2}$ fixation per gram of nodule was not significantly different from that of controls (Table 1). Although the data were not statistically different, $\mathrm{N}_{2}$ fixation ability of soybean nodules grown in trifluralin-treated soil was $\approx 1.8$ times greater than that of nodules grown in untreated soil $(82.7 \mathrm{vs} .45 .0 \mathrm{nmol}$ $\mathrm{C}_{2} \mathrm{H}_{2} / \mathrm{g}$ per h $\mathbf{x} 10^{2}, P>\mathrm{F}$ : 0.18$)$. Further study is required to determine if enhanced specific nitrogenase activity fixation is a means by which treated soybean plants compensate for poor modulation.

Table 3. Nitrogenase activity (actylene reduction) by nodules of soybean vacuum-infiltrated with diazinon.

\begin{tabular}{cc}
\hline $\begin{array}{c}\text { Diazinon } \\
\text { imbibition rate }\end{array}$ & $\begin{array}{c}\text { Nitrogenase activity } \\
\left.\text { (nmoles } \mathrm{C}_{2} \mathrm{H}_{4} / \mathrm{g} \text { per } \mathrm{h} \times 10^{2}\right)^{\mathrm{y}}\end{array}$ \\
\hline $3.0 \times$ & $1.6^{* *}$ \\
0.0 & 24.3 \\
$1.0 \times$ & $0.6^{* *}$ \\
0.0 & 22.5 \\
$0.5 \times$ & $0.6^{* *}$ \\
0.0 & 11.0 \\
$0.25 \times$ & $1.2^{*}$ \\
0.0 & 11.0 \\
\hline
\end{tabular}

${ }^{2} x=$ recommended rate.

YTreatment means were significantly different at $P \geq \mathrm{F}=0.01\left(^{* *}\right)$ and at $P \geq \mathrm{F}=0.05\left(^{*}\right)$ when compared to appropriate controls. 
Nitrogenase. Nitrogenase activity of excised nodules was severely reduced by exposure to diazinon at all rates tested (Table 3). This result suggests that diazinon may affect nitrogenase function directly. The concentration of diazinon within the imbibed nodules, however, was undoubtedly many times higher than would occur from foliar application and absorption. This difference may explain why nitrogenase activity was significantly depressed in nodules imbibed with the $1 \times$ and lower label rates of diazinon, but was not affected at the $1 \times$ foliar application rate. Diazinon has a short half-life (Ruzicka, 1967) and is metabolized rapidly in plants (Rails et al., 1966), The short-term $\mathrm{N}_{2}$ fixation inhibition (Table 2) may have been due to the nonpersistent character of diazinon in plants.

Rhizobium. Trifluralin and methomyl were nontoxic to $B$. japonicum (strain 61A116) and $R$. leguminosarum biovar phaseoli (strain 127E15), even at the highest rate (data not shown). Mallik and Tesfai (1985), in contrast, reported that trifluralin inhibited growth of 10 strains of $B$. japonicum. Other investigators agreed that the degree of pesticidal inhibition of rhizobia varies among strains (Kapustra et al., 1973; Tu, 1980, 1981). Strain 61A118, used in this study, appeared more resistant to trifluralin than those used by Mallik and Tesfai (1985).

Because neither pesticide was toxic to rhizobia, the pesticidal influence on modulation may have been due to altered plant physiological reactions. Trifluralin is absorbed by the root and emerging shoot of germinating crops (Hawxby et al., 1972; Parker, 1966) and is degraded very slowly in most higher plants. The compound interferes with cell division by binding to tubulin, thus preventing its assembly into microtubules (Bartels and Hilton, 1973; Hess and Bayer, 1974). Lateral root formation in primary roots of cotton (Gossypium hirsutum L.) is initiated but then halted by the inhibitory effect of trifluralin on cell division in the pericycle (Bayer et al., 1967). Modulation depression in legumes caused by trifluralin may be related to nodules arising from the division and growth of cortical and pericycle cells.

Depression of soybean modulation by the $3 \times$ rate of methomyl was not explained by these studies. Methomyl can be degraded to $\mathrm{CO}_{2}$ and acetonitrile in several crops (Harvey and Reiser, 1973), or in soil by microbial action (Harvey and Pease, 1973). Further investigations are needed to determine methomyl effects on soybean modulation.

Additional work in the general area of pesticide-nitrogen fixation interactions is needed, in part due to the mass of conflicting information. Additionally, differences among plants and chemicals are apparent. Studies should include interaction between plant species and cultivars and Rhizobium strains, growth medium, and the environment on pesticide effects on nitrogen fixation. Some standardization of technique maybe considered in future studies to allow reasonable and realistic comparison between sets of data.

\section{Literature Cited}

Alaa-Eldin, M. N., S. Mahmoud, A. Makawi, M. Abdel-Nasser, and N. Herzallah. 1981. Effect of preemergence application of some herbicides on modulation, nitrogen fixation and growth of soybean. Pesquisa Agropecuaria Brasileira 16:883-889.

Bartels, P.G. and J.L. Hilton. 1973. Comparison of trifluralin, oryzalin, pronamide, propham, and colchicine treatments on microtubules. Pest. Biochem. Physiol. 3:462-472.

Bayer, D. E., C.L. Fey, T.E. Mallory, and E.G. Cutter. 1967. Morphological and histological effects of trifluralin on root development. Amer. J. Bot. 54:945-952.

Bethlenfalvay, G. J., R.F. Norris, and D.A. Phillips. 1979. Effect of bentazon, a hill reaction inhibitor, on symbiotic nitrogen-fixing capatability and apparent photosynthesis. Plant Physiol. 63:213-215.

Bollich, P. K., E.P. Dunigan, and W.M. Jadi. 1985. Effects of seven herbicides on $\mathrm{N}_{2}\left(\mathrm{C}_{2} \mathrm{H}_{4}\right)$ fixation by soybeans. Weed Sci. 33:427-430.

Chamber, M.A. and F.J. Montes. 1982. Effects of some seeds disinfectants and methods of rhizobial inoculation on soybean (Glycine max L. Merrill). Plant \& Soil 66:353-360.

Curley, R.L. and J.C. Burton. 1975. Compatibility of Rhizobium japonicum with chemical seed protestants. Agron. J. 67:807-808.

Fischer, A. and A. Tasistro. 1981. Effect of certain herbicides upon the Rhizobium phaseoli-Phaseolus vulgaris symbiosis. Proc. EWRS Symp. on the Use of Soil Applied Herbicides. Versailles, France. p. 120-128.

Harvey. J., Jr. and H.L. Pease. 1973. Decomposition of methomyl in soil. J. Agr. Food Chem. 21(5):784-786.

Harvey, J., Jr. and R.W. Reiser. 1973. Metabolism of methomyl in tobacco, corn and cabbage. J. Agr. Food Chem. 21(5):775-783.

Hawxby, K., E. Basler, and P. Santelmann. 1972. Temperature effects on absorption and translocation of trifluralin and methazole in peanuts. Weed Sci. 20:285-289.

Hensley, D.L. and P.L. Carpenter. 1979. The effect of temperature on $\mathrm{N}_{2}$ fixation $\left(\mathrm{C}_{2} \mathrm{H}_{4}\right.$ reduction $)$ by nodules of legume and actinomycetednodulated woody species. Bet. Gaz. 140:58-64.

Hess, F.D. and D.E. Bayer. 1974. The effect of trifluralin on the ultrastructure of dividing cells of the root meristem of cotton (Gossypium hirsutum L. 'Acala 442'). J. Cell. Sci. 15:429-441.

Hoagland, D.R. and D.I. Arnon. 1950. The water-culture method for growing plants without soil. Univ. of California Agr. Expt. Sta., Circ. 347.

Kapustra, G. and D.L. Rouwenhorst. 1973. Interaction of selected pesticides and Rhizobium japonicum in pure culture and under field conditions. Agron. J. 65:112-115.

Kust, C.A. and B.E. Struckmeyer. 1971. Effects of trifluralin on growth, modulation, and anatomy of soybeans. Weed Sci. 19:147-152.

Ljunggren, H. and A. Martensson. 1980. Herbicides effect on leguminous symbiosis. Weeds and Weed Control, Proc. 21st Swedish Weed Conf. Uppsala, Sweden. p. 99-106.

Mallik, M.A.B. and K. Tesfai. 1983. Compatibility of Rhizobium japonicum with commercial pesticides in vitro. Bul. Environ. Contain. Toxicol. 31:432-437.

Mallik, M.A.B. and K. Tesfai. 1985. Pesticidal effect on soybean rhizobia symbiosis. Plant \& Soil 85:33-41.

Ott, L. 1988. An Introduction to statistical methods and data analysis. 3rd ed. PWS-KENT, Boston.

Parker, C. 1966. The importance of shoot entry in the action of herbicides applied to the soil. Weeds 14: 117-121.

Parker, M.B. and C.C. Dowler. 1976. Effects of nitrogen with trifluralin and vernolate on soybeans. Weed Sci. 24: 131-133.

Rails, J. W., D.R. Gilmore, and A. Cortes. 1966. Fate of radioactive O,Odiethyl O-(2-isopropyl-4-methylpyrimidin-6- yl) phosphorothioate on field-grown experimental crops. J. Agr. Food Chem. 14:387-392.

Ruzicka, J. H., J. Thomson, and B.B. Wheals. 1967. The gas chromatographic determination of organophosphorus pesticides. II. A comparative study of hydrolysis rates. J. Chromatogr. 31:37.

Schenelle, M. and D. Hensley. 1990. Effects of pesticides upon nitrogen fixation and modulation by dry bean. Pest. Sci. 28:83-88.

Staphorst, J.L. and B.W. Strijdom. 1976. Effects on rhizobia of fungicides applied to legume seed. Phytophylactia 8:47-54.

Tu, C.M. 1980. Effect of fungicides on growth of Rhizobium japonicum in vitro. Bul. Environ. Contain. Toxicol. 25:364-368.

Tu, C.M. 1981. Influence of pesticide seed treatments on Rhizobium japonicum and symbiotically grown soybean in soil under laboratory conditions. Prot. Ecol. 3:41-46.

Vincent, J,M. 1970. The cultivation, isolation and maintenance of rhizobia. A manual for the practical study of root-nodule bacteria. Blackwell, Oxford, U.K. IBP Hdbk. 15:120-128.

Wax, L. M., R.L. Bernard, and R.M. Hayes. 1974. Response of soybean cultivars to bentazon, bromoxynil, chloroxuron, and 2,4-DB. Weed Sci. 22:35-41. 